\title{
Effect of School Management on Teachers' Commitment: A Case of Government Secondary Schools in Arusha City, Tanzania
}

\author{
Augustino Mwamatandala* and Dr. Mussa S. Muneja \\ University of Arusha, Tanzania
}

*Corresponding Author: mwamatandalaaugustino@gmail.com

\begin{abstract}
This study sought to establish the effects of school's management on teachers' commitment among public secondary schools in Arusha City. The study employed quantitative research approach in collecting and analyzing data in that closed ended questionnaire was filled by 140 randomly selected teachers. Data for the first and second research questions on school management effectiveness and teachers' commitment was analyzed through descriptive statistics while the third research question was analyzed through Pearson Correlations. The findings revealed that management in schools under investigation is effective and teachers are committed toward accomplishment of school goals. Secondly, the study revealed a significant relationship between school management effectiveness and teacher's commitment. This study recommends that the management in schools under investigation should enhance management effectiveness in order to realize improved teachers' commitment which is essential for academic performance and realization of school goals and objectives.
\end{abstract}

Keywords: School management, effectiveness, commitment, heads of schools.

\section{Introduction}

Education is an important tool for promoting development. It is the foundation of knowledge and skills. In order to achieve the purpose of education, school resources must be managed effectively (Agih, 2015). Therefore, school managers such as principals and heads of schools are important persons in managing resources and supervising the teaching and learning process for educational goals to be realized (Rashid, 2013; World Bank, 2018). Teachers are important human resources that should be managed effectively to ensure delivery of quality education. Komba and Nkumbi (2008) assert that teachers are important persons in the educative process because they provide knowledge, skills, wisdom, appropriate orientations and inspiration to students. Stronge (2007) adds that an effective teacher listens to students, understands students' needs and problems and address such students' needs and concerns effectively. Scholars such as Mart (2013), Altun (2017) and Adhikary (2018) collectively observe that a committed teacher is one who is ready to address learning difficulties and motivates students to develop interests toward active learning. This in turn helps to promote moral and intellectual development of students.

Government schools in different countries face the challenge in retaining committed teachers. In the USA, for instance, at least $7 \%$ of teachers with less than 3 years of working experience leave the teaching profession (Hanushek, 2007). Moreover $16 \%$ of teachers in public schools quit teaching every year (Goldring et al., 2014). This problem largely occurs among schools with shortage of teaching and learning resources (Redding, 2018).Canada also experiences turnover rate among new teachers by $30 \%$ and the problem is attributed to stress resulting from lack of work-life balance and motivation from school leadership (Kutsyuruba at al., 2013).

In the context of developing countries, studies have documented the problem of teachers' commitment. A study done in Seychells by Comarmond et al. (2016) has shown that some secondary school teachers were uncertain about remaining in the teaching profession due to students' misconduct 
and inadquacy of resources. Another study by Mampane (2012) in South Africa indicates that schools face the challenge of teachers' turnover due to lack of job satisfaction attributed to low salaries. This further leads to absentism and resistance to work in rural areas.

In Tanzania, several studies have indicated the phenomenon of deteriorated teachers' commitment. Mkumbo (2012), for instance, found that there is a low level of commitment among teachers in government schools. Mwesiga and Okendo (2018) found that in Kagera Region, teachers have low teaching commitment due to poor training, inadquate participation in decision making, low salaries and lack of motivation. Moreover, studies by Betweli (2013), Bilinga and Mfaume (2017) and Mgonja (2017) indicated that Tanzanian government secondary school teachers are not committed to the extent that they engaged in professional misconduct such as absenteeism which undermine effective teaching and learning activities.

Curbing the issue of teachers' lack of commitment, effective school management is a mechanism for promoting the required commitment. Effective school management requires committed teachers who are ready to address students' learning difficulties (Stronge, 2007; World Bank 2018). Several Studies have shown that school management can enhance teachers' commitment. For instance, studies done in Europe indicate that school leadership has a role to play toward teachers' commitment. A Meta-analysis study by Aydin et al. (2013) revealed that transformation leadership style positively influences teachers' commitment in Turkey. In the context of North America, studies indicate the importance of school management for teachers' commitment. Geijsel et al. (2013) in Canada found that transformational leadership constitutes factors that affect teachers' commitment. Similarly, Marshall (2015) found that there is relationship between school principals' leadership styles and teachers' commitment.

In Asia, studies have shown the effect of school management on teachers' commitment. A study by Duo et al. (2016), for instance, indicates that school management aspects such as leadership styles, autonomy and job satisfaction largely influence organizational commitment among teachers in China. Additionally, Liu (2015) in China revealed that school leadership aspects such as culture and strategy influence teachers' commitment.

In Africa, studies indicate the effects of school management on teachers' commitment. A study by Khumalo (2019), for instance, conducted in South Africa, reveals that transformational leadership through involvement and participation helps to promote teachers' motivation which ultimately encourages teachers' commitment. Another study by Tadesse (2019) found that mentoring of inexperienced teachers influenced commitment among new teachers in Ethiopia. In Kenya, findings of a study done by Oduk (2016) indicated that transformational leadership style influences teachers' job commitment.

In Tanzania, the guidelines for school supervision empower head teachers to manage school resources including teachers (The Ministry of Education and Vocational Training, 2009). Yet studies done in the country have consistently shown that government school teachers lack commitment in teaching while engaging in professional misconduct due to low salaries, poor working conditions and negative attitude toward the teaching profession (Mkumbo, 2012; Betweli, 2013; Mgonja, 2017 and Mfaume \& Bilinga, 2017). More importantly studies done in Arusha City indicate that teachers' commitment in public secondary schools is lower than in private secondary schools(Ngussa and Gabriel (2017) which is affected by shortage of resources and poor working conditions ( Shanjiko, 2017).

This study therefore investigates on the effect of school management on teachers' commitment among public secondary schools in Arusha City in Tanzania. The study was guided by the following research questions:

1. How effectiveness is the school management among government secondary schools in Arusha City?

2. What is the levels of the teachers commitment among government secondary schools in Arusha City?

3. Is there significantrelationship between school management and teachers' commitment among government secondary schools in Arusha City? 
The third research question called for testing of the the following hypothesis.

$\boldsymbol{H 1}$ : There is no significant relationship between school management and teacher's commitment among government secondary schools in Arusha City.

H2: There is a significant relationship between the school management and teachers commitment among government secondary schools in Arusha City.

\section{Related Literature and Studies}

This section presents theoretical and empirical literature which has guided the study. The section includes theoretical framework and empirical studies related to the research problem.

\section{Theoretical Framework}

The study was guided by the theory of human needs developed by Abraham Maslow. Maslow assumed that human beings have a wide range of needs which are arranged hierarchically in five levels based on importance. The first level includes physiological or biological needs. These are needs which come first and they are necessary for survival. These needs include food, water and air. After satisfying such physiological needs, the next level are safety needs which are important for human protection. Human beings need protection from danger and threats. The following level is composed of social or belonging needs whereby human beings desire to be loved and accepted by peers and colleagues. Next to belonging needs are esteem needs which are related to self-respect and desire to be respected, recognized and appreciated by others. The last and highest level of needs constitutes selfactualization in which human beings aspire to realize individual potential, self-development and creativity (Mosley et al., 2015).

The theory is relevant to the topic because it highlights motivational factors which influence teachers' commitment. Therefore, school management can be effective if it is able to meet teachers' needs such as adquate salaries, condusive working conditions and promotions.

\section{Empirical Literature Review}

This part presents the empirical literature review about school management and teachers' commitment.

\section{Studies oneachers' Commitment}

Various studies have investigated on the levels of teachers' commitment. Khumalo et al., (2019), for instance, researched on the role of transformational school leadership in promoting teacher commitment and found that effective leadership motivates teachers' commitment. Gatsinzi et al. (2014) studied about work and school related variables and found that teacher commitment is influenced by the organization set up, students, career continuance and professional knowledge base.

Olurotimi et al. (2015) investigated the influence of motivational factors on teachers' commitment in public Secondary School in Mbale Municipality in Nigeria and found that teachers' commitment is influenced by rewards such as pay, recognitions and promotion opportunities. In a similar vein, Alsiewi and Agil (2014) analyzed factors that influence affective commitment to teaching in Libya. Analysis of data via regression analysis showed that job satisfaction factors such as positive attitude towards the job, growth and development opportunities and relevance and meaning of the job influenced teachers' commitment.

From previous findings, it is shown that teachers' commitment has two levels. The first level includes monetary factors such as pay and promotions. The second level includes non-monetary factors such as recognition, positive attitude towards teaching and development opportunities.

\section{School Management and Teachers' Commitment}

Studies have shown the relationship between school management and teachers' commitment. Eliophotou-Menon and Ioannou (2016) in Androula investigated the link between transformational leadership and teachers job satisfaction and commitment. The study found that school leadership influences commitment through teamwork, job satisfaction, participative decision making, openness, dedication to duty, decreased disagreements and conflicts as well as increased desire to remain in the organization.

Marshall (2015) studied the influence of principal leadership style on teachers' commitment among secondary schools in Barbados and found that there is a close relationship between leadership style and teacher commitment. Similarly, Dou et al. (2016) investigated about the relationships between school principal leadership, teachers' job satisfaction and organizational commitment and found a significant 
influence of instructional and transformational leadership on teachers' job satisfaction and organizational commitment in china.

Geijsel et al. (2003) studied about the effect of transformational leadership on teachers' commitment in Canada and Netherlands. The study found that leadership dimensions affect teachers' commitment. The study further indicated that having a well-established learning management system in the learning institution reinforces the teachers 'commitment.

Nyamubi and Gilman (2018) in Tanzania investigated on the contribution of school leadership styles on teachers' organizational commitment and found that leadership qualities among heads of schools contribute significantly in maintaining teachers' commitment and readiness to invest efforts in realizing school common vision. Mgani (2013) in Tanzania studied about leadership styles and school functioning among Kilosa District secondary schools and revealed that school management is a vital tool for teacher's commitment.

In conclusion, while studies have generally shown that there is relationship between school management and teachers' commitment, this study investigates on the same in the context of secondary schools in Arusha City.

\section{Research Methodology}

This section addresses the methodology used to guide the study.

\section{Research Design}

This study used the survey research design. According Yin (2009) survey research design allows meaningful and detailed investigation of characteristics of real-life events such as individuals, small group behavior, organizational and managerial processes and school management. The design enabled the researcher to analyze the effect of school management on teacher's commitment by surveying government secondary across Arusha City.

\section{Population and Sampling}

The study was based on the population of 220 teachers from government secondary schools in Arusha City. A sample size of 140 respondents was selected by using stratified random sampling techniques.

The stratified sampling technique was used because it guaranteed the possibility that teachers from each school had equal chance to be selected. In implementing the random sampling in each school, teachers were given some cards (Yellow and Green) which were well mixed; those who picked the yellow cards were selected.

\section{Data Collection Methods}

Data were collected through questionnaire. According to McMillan and Schumacher (2001), questionnaires can cover a large number and area compared to other methods of data collection. The questionnaire form was composed of close ended items whereby respondents were required to indicate their level of agreement or disagreement as follows: $1=$ Strongly Disagree, $2=$ Disagree, $3=$ Agree and $4=$ Strongly Agree. This gave freedom for the respondents to have a wide range of choice among the suggested options.

\section{Data Analysis}

In this study, data was collected, coded and then entered in the SPSS software. Data about school management and the levels of teachers' commitment were analyzed using descriptive statistics in terms of mean scores and standard deviation.

Interpretation of teacher' response was based on the following scale: $3.50-4.00=$ strongly agree, 2.50 $3.49=$ agree, $1.50-2.49=$ disagree and 1.00-1.49= strongly disagree. The relationship between school management and teachers' commitment was analyzed using Pearson Correlation Coefficient.

Table 1: Reliability of Data

\begin{tabular}{lcc}
\hline Variable & Items & C. Alpha \\
\hline School Management & 15 & .924 \\
Teachers' Commitment & 15 & .898 \\
\hline
\end{tabular}

\section{Validity and Reliability}

Two experts in school leadership were consulted to validate the questionnaire prior to data collection. While reliability is the degree to which a test is consistent and stable in measuring whatever it is measuring, the reliability was ensured through a pilot study which was done to 30 government secondary school teachers from Monduli District in Tanzania. The reliability results are show in table 1 with a Cronbach's alpha of .924 and .898 for School management and Teacher's Commitment respectively. 


\section{Analysis and Results}

This section presents the findings. The presentation is based on research questions that guided the study and testing of hypothesis.

\section{Descriptive Analysis}

This section analyzes the first two research questions regarding effectiveness of school management and teachers' commitment.

Research Question 1: How effective is the school management among government secondary schools in Arusha City?

This question sought to determine the perceptions of respondents on the effectiveness of the school management. Respondents were asked to rank their levels of agreement or disagreement with 13 closed ended items in the questionnaire. Data were analyzed using means and standard deviation as seen in table 2. In Table 2, respondents agreed with all the items regarding effectiveness of school management. The most agreed areas of effectiveness in school management were good communication $(\mathrm{M}=3.13, \mathrm{~S} . \mathrm{D}=0.72510)$; promotion of career and professional growth (M=3.04, S.D= $0.70831)$ and valuing teachers' opinions and ideas $(\mathrm{M}=3.02, \mathrm{~S} . \mathrm{D}=0.68031)$.

Table 2: Teachers' Perception on School Management Effectiveness

\begin{tabular}{llccc}
\hline SN & \multicolumn{1}{c}{ Perception on School Management Effectiveness } & Mean & Std. Dev & Interpretation \\
\hline 1 & School management ensures good communication with teachers & 3.13 & .72510 & Agree \\
2 & School management promotes career and professional growth & 3.04 & .70831 & Agree \\
3 & School management value the teacher's opinions and ideas & 3.02 & .68031 & Agree \\
4 & School management ensure that teachers rights are well respected & 2.98 & .71563 & Agree \\
5 & School management promotes freedom to make decisions & 2.95 & .74789 & Agree \\
6 & School management ensures good relationship among teachers & 2.94 & .79941 & Agree \\
7 & School management encourage participation in decision making & 2.94 & .65397 & Agree \\
8 & School management ensures teachers get necessary material & 2.91 & .77141 & Agree \\
9 & School management conducts fair teachers' performance appraisal & 2.91 & .68683 & Agree \\
10 & School management ensues that teachers are treated well & 2.90 & .75890 & Agree \\
11 & School management solves teachers' problems & 2.82 & .81698 & Agree \\
12 & School management ensures good working condition & 2.75 &. .85259 & Agree \\
13 & School management ensures that teachers are promoted & 2.59 & 1.0229 & Agree \\
\hline
\end{tabular}

The second most agreed areas included school management is effective in promoting respect of teachers' rights $(M=2.98, S . D=0.71563)$, school management is effective in promotion of teachers' freedom in decision making ( $M=2.95, S . D=0.74789)$; school management promotes good relationship among teachers $(M=2.94, S . D=0.79941)$; school management encourages participation in decision making $(M=2.94 ; \quad S . D=0.65397)$, school management is effective in ensuring that teachers get necessary materials $(M=2.91, S . D=0.77141)$; school management is effective in ensuring fair teachers' performance appraisal $(M=2.91$, S.D= 0.68683 ) and school management is effective in ensuring teachers are treated well $(M=2.90, S . D=$ 0.75890).

The least agreed responses were regarding school management being effective in solving teachers' problems $(M=2.82, \quad S . D=0.81698)$, school management being effective in ensuring good working conditions ( $M=2.75, S . D=0.85259)$ and school management being effective in ensuring that teachers are promoted on time $(M=2.59, S . D=$ 1.0229).

Research Question 2: What is the levels of the teachers commitment among government secondary schools in Arusha City?

The second research question asked respondents to indicate their perception on teachers' level of commitment. The perceptions were measured by 15 items in the questionnaire. Data was analyzed using means and standard deviation as seen in table 3.

From Table 3, respondents agreed that teachers in government secondary schools are committed. The first most agreed areas of teachers' commitment included that teachers are ready to improve their professional skills ( $M=3.36, S . D=0.54601)$; teachers are able to help learners in mastering skills ( $M=$ 3.27, S.D=0.61603); teachers are willing to assist students during the learning process $(M=3.27$, S.D $0.67882)$; teachers plan and organize the teaching very well $(M=3.26, S . D=0.59958)$; teachers spend longer time in schools $(M=3.24, S . D=0.66713)$; 
Table 3: Teachers' Perception on their Commitment

\begin{tabular}{llccc}
\hline SN & Teachers' Perception on their Commitment & Mean & Std. Dev & Interpretation \\
\hline 1. & Teachers are ready to improve their professional skills & 3.36 & .54601 & Agree \\
2. & Teachers are able to help learners in mastering skills & 3.27 & .61603 & Agree \\
3. & Teachers are willing to assist students learning & 3.27 & .67882 & Agree \\
4. & Teachers are able to plan and organize teaching & 3.26 & .59958 & Agree \\
5. & Teachers spend longer hours in school & 3.24 & .66713 & Agree \\
6. & Teachers are able to work in team with colleagues & 3.23 & .66392 & Agree \\
7. & Teachers are confident with their profession & 3.22 & .62259 & Agree \\
8. & Teachers have positive attitude toward the professional & 3.22 & .56796 & Agree \\
9. & Teachers have willingness and passion & 3.17 & .62579 & Agree \\
10. & Teachers are creative enough to delivery effectively & 3.12 & .72097 & Agree \\
11. & Teachers have improved their working interest & 3.11 & .61432 & Agree \\
12. & Teachers are committed to search materials for students & 3.11 & .88538 & Agree \\
13. & Teachers are committed report at work early & 3.00 & .81650 & Agree \\
14. & Teachers have high working morale & 2.98 & .87405 & Agree \\
15. & Teachers feel satisfied with their profession & 2.91 & .96673 & Agree \\
\hline
\end{tabular}

Table 4: Effect of School Management on Teachers' Commitment

\begin{tabular}{llcc}
\hline & & EFFECTIVENESS & COMMITMENT \\
\hline EFFECTIVENESS & Pearson Correlation & 1 & $.570^{* *}$ \\
& Sig. (2-tailed) & & .000 \\
COMMITMENT & $\mathrm{N}$ & 124 & 124 \\
& Pearson Correlation & $.570^{* *}$ & 1 \\
& Sig. (2-tailed) & .000 & 124 \\
\hline
\end{tabular}

**. Correlation is significant at the 0.01 level (2-tailed).

The second most agreed item son teachers' commitment included that teachers have willingness and passion $(M=3.17, S . D=0.62579)$; teachers are creative to deliver effectively $(M=3.12$, $S . D=0.61432)$; teachers have improved their working interests $(M=3.11, S . D=0.61432)$ and teachers are committed to search for materials to help students $(M=3.11, S . D=0.88538)$

The least agreed items were that teachers are committed to report to work early ( $M=3.00, S . D=$ $0.81650)$; teachers have high working morale $(\mathrm{M}=$ $2.98, S . D=.87405)$ and teachers feel satisfied with their profession.

Research Question 3: Is there significant relationship between school management effectiveness and teachers commitment among government secondary schools in Arusha City?

The third research question sought to establish whether there is any significant relationship between school management effectiveness and the commitment of teachers. This research question called for testing of a null hypothesis which stated: there is no significant relationship between school management effectiveness and teachers commitment among selected government secondary schools in Arusha City. The Findings are presented in Table 4.

Table 4 shows that the null hypothesis was tested through the Pearson Product Moment Correlation Coefficient. The table indicates the Pearson Correlation of .570 with the Sig of .000 which is lower than the critical value suggesting that the correlation is positive and significant. Therefore, the null hypothesis is rejected and we maintain that there is a significant relationship between school management effectiveness and teachers commitment. Since the relationship is positive, it implies that the better the school management effectiveness, the better the teachers' commitment. Therefore, school management effectiveness affects teachers' commitment in a positive way.

\section{Discussion of Findings}

Findings for the first research question showed that school management among government secondary schools in Arusha city is effective in promoting good 
communication, career and professional growth, valuing teachers' opinions and ideas, promotion of teachers' freedom in decision making, promotion of good relationship among teachers, encouraging participation in decision making, ensuring teachers get necessary materials, ensuring fair teachers' performance appraisal and ensuring teachers are treated well. The findings also showed that school management is effective in solving teachers' problems, ensuring good working conditions and ensuring that teachers are promoted on time. The findings are in harmony those by Brooke (2013) who investigated on effective school leadership in United States of America and found that effective school leadership promotes communication among teachers, freedom of speech, respect and meets needs of students and teachers. Lingam et al., (2014) in their study on Effectiveness of school strategic planning in Malaysia found that effective school management requires managers who succeed in carrying out the organizational goals and those who utilize the following leadership skills: planning (deciding how to accomplish the organization's goals); organizing (doing the necessary preparation); staffing (filling positions with the right people); directing (motivating staff so that goals are achieved); controlling (guiding the organization in the proper direction) and decision making (which underlies everything the manager accomplishes). The competent principal must therefore choose a time frame that fits the planning agenda and develops strategies to monitor progress.

From the second research question, respondents agreed that teachers are committed in improving their professional skills, teachers are able to help learners in mastering skills, teachers are willing to assist students during the learning process, teachers plan and organize the teaching very well, teachers spend longer time in schools, teachers are committed to work in teams and teachers are confident with their profession. These findings are similar with findings by Ibrahim et al (2014) who observed that commitment improves skills in teaching profession. Similarly, Stronge (2007) and World Bank (2018) argued that effective school management requires committed teachers who are ready to address learning difficulties of students.

Findings for the third research question showed that that there is a significant relationship between the school management effectiveness and teachers commitment. These findings are similar to previous studies by Marshall (2015), Eliophotou-Menon and loannou (2016) and Duo et al. (2016) who found that school management influences commitment through teamwork, job satisfaction, participative decision making, openness and dedication to duty.

\section{Conclusions and Recommendations}

This part presents the conclusions and recommendations of the study based on research questions that guided the study.

\section{Conclusions of the Study}

On basis of findings, the study draws three conclusions as follows:

Firstly, school management in government secondary schools in Arusha City is effective in ensuring good communication among teachers, promoting career and professional growth and promoting teachers' involvement in decision making, among others.

Secondly, the study concludes that teachers in government secondary schools of Arusha City are committed in improving teaching skills, helping learners to master subjects, organizing lessons, cooperating with colleagues and reporting to work on time.

Thirdly, the study concludes that teachers' commitment among government secondary schools in Arusha City is influenced by effectiveness in school management.

\section{Recommendations of the Study}

This study recommends that in order to maintain good school management in government secondary schools, school leaders should ensure good communication among teachers, promote career and professional growth and promote teacher's involvement in decision making.

This study also recommends that the government should improve teachers' commitment through promoting teachers on time, solving teachers' problems, provision of good working conditions and having proper treatment to teachers.

This study finally recommends that government secondary schools should improve the relationship between school management and teacher's commitment through provision of in service training, improving teachers' passion/willingness, increasing Teachers' readiness to work, improving 
teachers' working morale and improving working conditions.

\section{Reference}

Adhikary, M. C. (2018). Role of Teachers in Quality Enhancement Education and Human Development. International Journal of Humanities and Social Science Invention, 7(12), 34-41.

Agih, A. A. (2015). Effective School Management and Supervision: Imperative for Quality Education Service Delivery. African Research Review. An International Multidisciplinary Journal, Ethiopia,9(3) , 62-74.

Alsiewi, A. M., \& Agil, S. (2014). Factors that influence Affective Commitment to teaching in Libya. IOSR Journal of Business and Management,16(2), 37-46.

Aydin, A., Sarier, Y., \& Uysal, S. (2013). The Effect of School Principals' Leadership Styles on Teachers' Organizational Commitment and Job Satisfaction. Educational Sciences: Theory \& Practice,13(2), 806-811.

Betweli, O. (2013). The nature of teacher professional misconduct in Tanzania public primary schools: The case of Sumbawanga Municipality and Rural Districts.

International Journal of Education, 5(1), 81-93.

Brooke, E. (2013). Key Factors of Effective School Leadership. Retrieved from https://www.lexialearning.com/resources/ white-papers/four-key-factors-effectiveschool-leadership

Comarmond, O., Abbiss, J., \& Lovett, S. (2016). Commitment crisis: voices of secondary teachers. In B. Wever, R. Vanderlinde, M. Tuytens, \& A. Aelterman, Professional Learning in Education. Challenges for Teacher Educators, Teachers and Student Teachers (pp. 87-108). Ghent: Academia Press.

Duo, D., Devos, G., \& Valcke, M. (2016). The relationships between school autonomy gap, principal leadership, teachers' job satisfaction and organizational commitment. Educational

Management, Administration and Leadership,45(6), 959-977.

Eliophotou-Menon, M. and Ioannou, A. (2016). The Link between Transformational Leadership and Teachers' Job Satisfaction Commitment, Motivation and Trust in Leaders. Academy of Educational Leadership Journal July (2016).

Gatsinzi, P, Jesse Role, and Makewa, N, L (2014). Work and School Related Variables in Teacher Motivation in Gasabo District, Rwanda

Geijsel, F., Sleegers, P., Leithwood, K., \& Jantzi, D. (2003). Transformational leadership effects on teachers' commitment and effort toward school reform. Journal of Educational Administration,41(3) , 228-256.

Goldring, R., Taie, S., \& Riddles, M. (2014). Teacher Attrition and Mobility: Results from the 2012-13 Teacher Follow Up Survey. Washington, DC: National Center for Education Statistics.

Hanushek, E. A. (2007). The Single Salary Schedule and Other Issues of Teacher Pay. Peaboy Journal of Education,82(4) , 574-586.

Çolak, I., Altınkurt, Y. and Yilmaz, K. (2014). The Relationship between Teachers' Leadership Roles and Organizational Commitment Levels. Educational Process International Journal 3(1-2), 35-51.

Khumalo,S. S, Eveline O. and Anyolo (2019).School Leadership in Promoting Teacher Commitment., Journal of Teacher Education for Sustainability.

Komba, W., \& Nkumbi, E. (2008). Teacher Professional Development in Tanzania: Perceptions and Practices. Journal of International Cooperation in Education,11(3) , 67-83.

Kutsyuruba, B., Godden, L., \& Tregunna, L. (2013). Early-Career Teacher Attrition and Retention:A pan-Canadian document analysis study of teacher induction and mentorship programs. Kingston: Queens University. 
Lingam, G., Lingam, N., \& Raghuwaiya, K. (2014). Effectiveness of school strategic planning: The case of Fijian Schools. International Journal of Humanities and Social Sciences, 8(7), 2127-2133.

Liu, P. (2015). Motivating teachers' commitment to change through transformational school leadership in Chinese urban upper secondary schools. Journal of Educational Administration,53(6), 735-754.

McMillan, J. H., and Schumacher, S. (2001).

Research in Education. A Conceptual Introduction (5th ed.). New York: Longman.

Mampane, P. (2012). The Teacher Turnover Crisis: Evidence from South Africa. Business Education \& Accreditation,4(2), 73-83.

Mfaume, H., \& Bilinga, M. (2017). Prevalence of Teachers" Professional Malpractices in Tanzanian Public Secondary Schools: What Ought to Be Done? Journal of Education and Training Studies, 5(2), 43-52.

Mgani, V.A. (2013). The Effectiveness of Secondary School Budgets in the Implementation of School Projects in Kilosa District Morogoro. Unpublished M.ED. APPS Thesis, Open University of Tanzania, Dar es Salaam.

Mgonja, M. G. (2017). Responding to Workplace Absenteeism in Tanzania: The case study of Public and Private Schools in Ilala Municipality and Mkuranga District. International Journal of Educational Leadership and Management, 5 (1), 85-108.

Mart, C. T. (2013). A Passionate Teacher: Teacher Commitment and Dedication to Student Learning. International Journal of Academic Research in Progressive Education and Development,2(1), 437-442.

Marshall, I. A. (2015). Principal Leadership Style and Teacher Commitment among a Sample of Secondary School Teachers in Barbados. Journal of Arts and Humanities , 2015(4), 4358.

Mkumbo, K. (2012). Teachers' Commitment to, and Experiences of, the Teaching Profession in Tanzania: Findings of Focus Group Research.
International Education Studies,5(3), DOI:10.5539/ies.v5n3p222.

Mosley, D. C., Mosley, D. C., \& Pietri, P. H. (2015). Supervisory Management: The Art of Insipring, Empowering and Developing People. Stanford: Cengage Learning.

Mwesiga, A., \& Okendo, E. O. (2018). Levels of Teachers Commitment to the Teaching Profession in Secondary Schools in Kagera Region, Tanzania . Research on Humanities and Social Sciences,8(4), 117-127.

Ngussa, B. M., \& Gabriel, L. (2017). Participation in Decision Making and Teachers' Commitment: A Comparative Study between Public and Private Secondary Schools in Arusha Municipality, Tanzania. American Journal of Educational Research,5(7) , 801-807.

Nyamubi, G. J. (2018). The Contribution of School Leadership Styles on Teachers' Organisational Commitment. Asian Journal of Management Sciences \& Education,7(2), 158-168.

Oduk, J. M. (2016). Influence of Headteachers' Leadership Styles on Teachers' Job Commitment in Public Primary Schools in Rongo Sub-County, Migori County, Kenya (Master Dissertation). Nairobi: University of Nairobi.

Olurotimi, O. J., Asad, K. W., \& Abdulrauf, A. (2015). Motivational Factors and Teachers Commitment in Public Secondary Schools in Mbale Municipality. Journal of Education and Practice, 6(15) , 117-122.

Rashid, M. (2013). Determinants of Effective School Management:An Empirical Investigation to Explore ODL Prospects. Islamabad: University of Islamabad.

Redding, C. (2018, Sepetember 7). Teacher turnover is a problem-here is how to fix it. Retrieved fromtheconversation.com:https://theconve rsation.com/teacher-turnover-is-a-problemheres- how-to-fix-it-101584

Shanjiko, F. A. (2017). Roles of Head Teacher in Creating Conducive Work Environment: A Study of Selected Secondary Schools in 
Arusha City Council. Mwanza: St. Augustine University of Tanzania.

Stronge , J. H. (2007). Qualities of Effective Teachers. Alexandria: Association for Supervision and Curriculum Development.

Tadesse, E. F. (2019). Teachers' Organizational Commitment at Secondary School in Addis Ababa, Ethipia. International Journal of Education and Research,7(4), 53-68.
The Ministry of Education and Vocational Training. (2009). Guidelines for School Supervision. Dar es Salaam : Author .

World Bank. (2018, November 9). Education Management. Retrieved from worldbank.org: https://www. Worldbank .org/en/topic/education/brief/educationmanagement.

Yin, R. K. (2009). Case study research: Design and methods (4th Ed.). Thousand Oaks, CA: Sage. 